Briggs, M., Tull, G., Newland, L. G. M. \& Briggs, C. A. E. (1955). J. gen. Microbiol. 12, 503-512

\title{
The Preservation of Lactobacilli by Freeze-drying
}

\author{
By MARY BRIGGS, GRACE TULL, L. G. M. NEWLAND \\ AND C. A. E. BRIGGS \\ National Institute for Research in Dairying, University of Reading
}

\begin{abstract}
SUMMARY : In developing a technique for the freeze-drying of lactobacilli particular attention was paid to the percentage survival rate; this was estimated by viable counts immediately after drying and after storage of the dried cultures. The main factor influencing survival rate was the suspending medium, the best results being obtained in horse serum with $8 \%$ added glucose. Forty-four cultures, fourteen freshly isolated, representative of a comprehensive collection of 452 lactobacilli (see Briggs, 1953a) were freeze-dried in this vehicle using the apparatus and technique described. The majority of the survival rates were over $50 \%$ immediately after drying, and over $25 \%$ after 6 months storage; all but two of the freshly isolated strains dried well. Some of the dried cultures were tested again after a storage period of about 2 years and then showed satisfactory percentage survivals.
\end{abstract}

For taxonomic studies of 452 strains of lactobacilli (Briggs, 1953a) cultures were maintained in yeast glucose litmus milk plus chalk at $4^{\circ}$, which, although satisfactory for survival, involved considerable expenditure of media and labour; a less cumbersome method of maintenance was required, and the possibilities of freeze-drying were investigated.

Since no outstanding method for lactobacilli had been described, the technique which had proved satisfactory for the freeze-drying of streptococci at this Institute was examined. The effects of different methods of preparing the culture, of various suspending media and of other modifications of the freezedrying technique were studied by determining the percentage survivals immediately after drying and at intervals during storage. A freeze-drying technique was evolved using as test organisms strains of lactobacilli particularly sensitive to drying. The method was then applied to forty-four cultures representative of the eight groups of Briggs (1953a), including fourteen freshly isolated strains.

\section{METHODS}

In studying the conditions affecting the viability of lactobacilli during freezedrying and subsequent storage, the different factors involved were varied one by one. Deviations from, or comparisons with, the standard method described below are recorded in the appropriate places.

Apparatus. The apparatus, illustrated in Pl. 1, was similar to Swift's (1937) and also to that used by Proom \& Hemmons (1949), the chief components being an efficient vacuum pump ('Speedivac', W. Edwards and Co. (London) Ltd.), a desiccator and a large lagged box. Vacuum in the system was determined by means of an Edwards's 'Vacustat', and dry air was introduced as required through a column of silica gel. A manifold, taking ten tubes, was 
connected to the evacuating system and an Edwards's high frequency vacuum tester was used for the detection of vacuum in the tubes on the manifold and in the sealed tubes.

Standard drying technique. Cultures were incubated for $24 \mathrm{hr}$. anaerobically on slopes of $10 \mathrm{ml}$. tomato glucose Tween agar (T.G.T.A.; Briggs, $1953 \mathrm{~b}$ ). $0.5 \mathrm{ml}$. of separated milk $+3 \%$ lactose was added to each tube and the growth washed off. The suspensions were bulked, thoroughly mixed and $0 \cdot 1 \mathrm{ml}$., accurately measured in special pipettes, introduced into each drying tube, care being taken to deposit all the suspension in the bottom; $0 \cdot 1$ ml. quantities of suspension were also added to duplicate tubes of $10 \mathrm{ml}$. Ringer's solution for dilution and plating to give an estimate of the original viable count.

The drying tubes were placed in a dish of powdered solid $\mathrm{CO}_{2}$ for $3 \mathrm{~min}$. and then transferred to the desiccator which contained a basket to hold 400 tubes, and a large dish of $\mathrm{P}_{2} \mathrm{O}_{5}$. Solid $\mathrm{CO}_{2}$ had been stored in the lagged box overnight to cool it. The desiccator was placed in the box, connected to the evacuating system and the pump started. The pump was left running overnight (18 hr.), the vacuum reaching at least $0.01 \mathrm{~mm}$. of mercury. After the pump had been stopped dry air was introduced slowly and the tubes removed from the desiccator. The cotton-wool plugs were pushed half-way down the tubes and the glass constricted above the level of the plugs. The tubes were then evacuated on the manifold and sealed under vacuum. The dried cultures were stored at room temperature in the dark. Duplicate tubes required for estimating the viable count immediately after freeze-drying were not sealed but were reconstituted as soon as they were removed from the desiccator.

Reconstitution. Tubes were tested for vacuum, opened, and $0.1 \mathrm{ml}$. of sterile distilled water at room temperature was added to each tube. The contents of each tube were then transferred to $\mathbf{1 0} \mathrm{ml}$. Ringer's solution, the tube being washed out once with this solution.

Viable counts. The viable count before freeze-drying was estimated from the suspension to be dried. Tenfold dilutions were made in Ringer's solution and duplicate plates prepared for each dilution tested. To avoid the use of large numbers of anaerobic jars plates were prepared with double layers of agar, the lower consisting of T.G.T.A. containing $0.002 \mathrm{M}$-sodium mercaptoacetate and the bacterial suspension; this was covered with a layer of nutrient agar also containing $0.002 \mathrm{M}$-sodium mercaptoacetate. This method of plating proved satisfactory for all the species of lactobacilli used in the early work with the exception of Lactobacillus bulgaricus: for this species, and for a few others in later studies (Table 5) T.G.T.A. + mercaptoacetate plates were not covered with the upper layer of agar but were incubated in anaerobic jars. All plates were incubated for 3 days at the optimum temperature of the culture under test before being counted.

Organisms. The cultures used in this work were those studied by Briggs (1953a). In preliminary tests strains of Lactobacillus helveticus, $L$. casei and $\boldsymbol{L}$. brevis gave higher percentage survivals than $L$. acidophilus or L. bulgaricus. Therefore most of the early work was done with one strain of $L$. acidophilusA 1 (Briggs, $1953 a$ ). 


\section{RESULTS}

\section{Effect of the nature of the suspending medium}

Separated milk $+3 \%$ lactose had been used successfully for several years at this Institute for the freeze-drying of streptococci and was adopted for the lactobacilli as a standard. Three other suspending media were tested: horse serum, horse serum $+8 \%$ glucose and Naylor \& Smith's (1946) reducing medium. $8 \%$ concentration of glucose in horse serum was chosen so that the total sugar in the serum + glucose suspending medium approximated that in the milk+ lactose medium. Preliminary experiments showed that the immediate survival of Lactobacillus acidophilus A1 in serum alone was approximately $75 \%$ of that obtained in the standard milk + lactose medium; consequently serum alone was not tested further. Table 1 summarizes the results of experiments in which the numbers of viable organisms after freeze-drying in the standard milk medium were compared with those in serum + glucose and in the reducing medium.

Table 1. Effect of different suspending media on the survival of freeze-dried lactobacilli

Percentage survival after storage time

\begin{tabular}{|c|c|c|c|c|c|c|c|c|c|}
\hline \multirow[b]{2}{*}{ Strain } & \multirow{2}{*}{$\begin{array}{l}\text { Suspending } \\
\text { medium* }\end{array}$} & \multicolumn{4}{|c|}{ Weeks } & \multicolumn{4}{|c|}{ Months } \\
\hline & & $0 \dagger$ & 1 & 2 & 3 & 1 & 3 & 6 & 21 \\
\hline L. acidophilus A1† & $\begin{array}{l}\mathbf{A} \\
\mathbf{B}\end{array}$ & $\begin{array}{r}5 \cdot 1 \\
14 \cdot 4\end{array}$ & $\begin{array}{l}\text { nt } \\
\text { nt }\end{array}$ & $\begin{array}{l}\text { nt } \\
\text { nt }\end{array}$ & $\begin{array}{r}8 \cdot 4 \\
12 \cdot 5\end{array}$ & $\begin{array}{l}\text { nt } \\
\text { nt }\end{array}$ & $\begin{array}{l}28 \cdot 6 \\
35 \cdot 5\end{array}$ & $\begin{array}{l}14 \cdot 8 \\
35 \cdot 6\end{array}$ & $\begin{array}{l}\text { nt } \\
\text { nt }\end{array}$ \\
\hline L. acidophilus A1† & $\begin{array}{l}\mathbf{A} \\
\mathbf{C}\end{array}$ & $\begin{array}{l}36 \cdot 0 \\
10 \cdot 0\end{array}$ & $\begin{array}{r}29 \cdot 8 \\
2 \cdot 0\end{array}$ & $\begin{array}{l}\text { nt } \\
\text { nt }\end{array}$ & $\begin{array}{l}\text { nt } \\
\text { nt }\end{array}$ & $\begin{array}{l}\mathbf{5} \cdot \mathbf{3} \\
\mathbf{0} \cdot \mathbf{3}\end{array}$ & $\begin{array}{l}1 \cdot 9 \\
0.5\end{array}$ & $\begin{array}{l}6 \cdot 0 \\
1 \cdot 4\end{array}$ & $\begin{array}{l}\text { nt } \\
\text { nt }\end{array}$ \\
\hline L. acidophilus A6 & $\begin{array}{l}\mathbf{A} \\
\mathbf{B}\end{array}$ & $\begin{array}{l}\mathbf{3} \cdot 9 \\
\mathbf{2} \cdot 5\end{array}$ & $\begin{array}{l}\text { nt } \\
\text { nt }\end{array}$ & $\begin{array}{l}1 \cdot 2 \\
4 \cdot 8\end{array}$ & $\begin{array}{l}\text { nt } \\
\text { nt }\end{array}$ & $\begin{array}{l}2 \cdot 0 \\
2 \cdot 3\end{array}$ & $\begin{array}{c}\text { nt } \\
2 \cdot 6\end{array}$ & $\begin{array}{l}\text { nt } \\
\text { nt }\end{array}$ & $\begin{array}{l}\text { nt } \\
\text { nt }\end{array}$ \\
\hline L. bulgaricus $\mathbf{B 2}$ & $\begin{array}{l}\mathbf{A} \\
\mathbf{B} \\
\mathbf{C}\end{array}$ & $\begin{array}{r}22 \cdot 5 \\
18 \cdot 0 \\
2 \cdot 3\end{array}$ & $\begin{array}{l}\text { nt } \\
\text { nt } \\
\text { nt }\end{array}$ & $\begin{array}{r}12.4 \\
18.7 \\
0.6\end{array}$ & $\begin{array}{l}\text { nt } \\
\text { nt } \\
\text { nt }\end{array}$ & $\begin{array}{c}23 \cdot 1 \\
17 \cdot 2 \\
0 \cdot 04\end{array}$ & $\begin{array}{r}21.4 \\
23 \cdot 8 \\
0.7\end{array}$ & $\begin{array}{r}11.8 \\
16.5 \\
0.5\end{array}$ & $\begin{array}{r}7 \cdot 7 \\
14.5 \\
0 \cdot 03\end{array}$ \\
\hline L. pentoaceticus $\mathbf{E} 2$ & $\begin{array}{l}\mathbf{A} \\
\mathbf{B}\end{array}$ & $\begin{array}{l}14 \cdot 9 \\
67 \cdot 2\end{array}$ & $\begin{array}{l}\text { nt } \\
\text { nt }\end{array}$ & $\begin{array}{l}23 \cdot 2 \\
23 \cdot 9\end{array}$ & $\begin{array}{l}\text { nt } \\
\text { nt }\end{array}$ & $\begin{array}{r}6 \cdot 7 \\
35 \cdot 7\end{array}$ & $\begin{array}{r}5 \cdot 0 \\
18 \cdot 2\end{array}$ & $\begin{array}{l}\text { nt } \\
\text { nt }\end{array}$ & $\begin{array}{l}\text { nt } \\
\text { nt }\end{array}$ \\
\hline L. casei $\mathbf{H} 1$ & $\begin{array}{l}\mathbf{A} \\
\mathbf{B}\end{array}$ & $\begin{array}{l}82 \cdot 9 \\
77 \cdot 6\end{array}$ & $\begin{array}{l}\text { nt } \\
\text { nt }\end{array}$ & $\begin{array}{l}60 \cdot 5 \\
71 \cdot 1\end{array}$ & $\begin{array}{l}\text { nt } \\
\text { nt }\end{array}$ & $\begin{array}{l}56 \cdot 5 \\
77 \cdot 6\end{array}$ & $\begin{array}{l}31 \cdot 8 \\
45 \cdot 2\end{array}$ & $\begin{array}{l}\text { nt } \\
\text { nt }\end{array}$ & $\begin{array}{l}\text { nt } \\
\text { nt }\end{array}$ \\
\hline
\end{tabular}

* A: separated milk +3\% lactose; B: horse serum +8 \% glucose; C: Naylor \& Smith's (1946) reducing medium.

$\dagger$ Immediately after freeze-drying. $\quad \ddagger$ Results of separate experiments.

nt $=$ not tested.

Despite variations between the results of replicate experiments the data in Table 1 show that the reducing medium (C) gave considerably lower survival rates than either of the other suspending media. Serum + glucose gave more satisfactory survivals than milk + lactose. Fig. 1, in which the log. of the viable count has been plotted against time, illustrates the results obtained with Lactobacillus bulgaricus $\mathbf{B 2}$ in the milk and serum suspending media. As the storage time increased, the loss of viability in serum + glucose was less than in milk+lactose. 
The superiority of the serum + glucose suspending medium in these experiments warranted its use in further studies, described later, with representative strains of lactobacilli.

\section{Effect of reconstitution temperature}

Six tubes of Lactobacillus acidophilus A 1 which had been freeze-dried by the standard method (p. 504) were opened, and three reconstituted with sterile distilled water at room temperature and three with water at $50^{\circ}$. The former showed an average count of $4.8 \times 10^{6} /$ tube $(0.1 \mathrm{ml}$.), corresponding to $40 \%$ survival of the original, whilst those reconstituted at $50^{\circ}$ showed a count of $3.6 \times 10^{6} /$ tube, representing $30 \%$ survival; these results are in agreement with those of Speck \& Myers (1946). Henceforth, all tubes were reconstituted with water at room temperature.

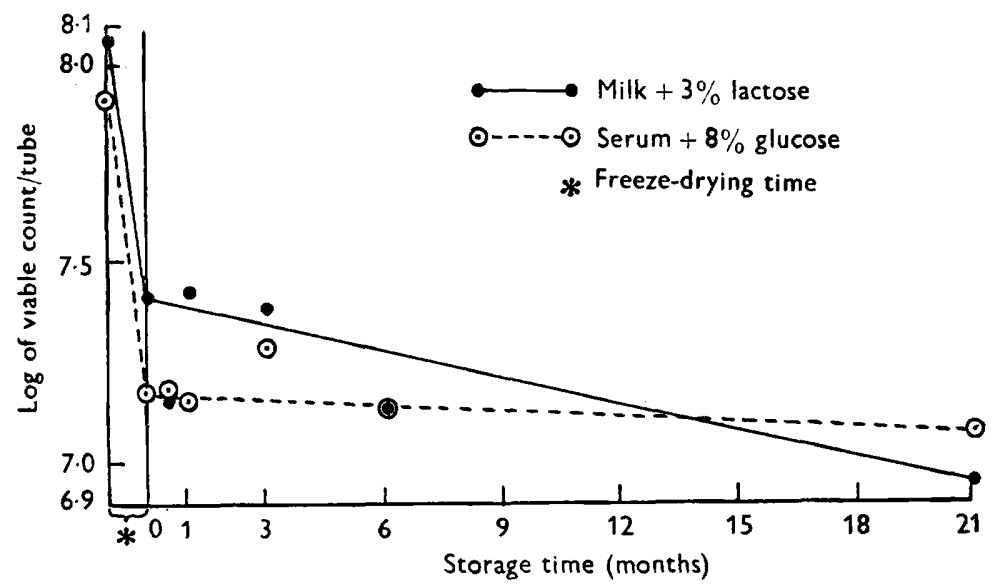

Fig. 1. Survival of Lactobacillus bulgaricus B2 after freeze-drying and storage in two suspending media.

\section{Effect of different methods of preparing the cultures}

Since the large quantities of acid which some strains of lactobacilli produce might be detrimental to the organisms during both freeze-drying and storage, it was anticipated that cultures grown on slopes would be more suitable for drying than organisms from broth, in which some strains can produce a $\mathrm{pH}$ value of 3.5 or less in $24 \mathrm{hr}$. Lactobacillus acidophilus (A 1) was grown on T.G.T.A. slopes and in tomato glucose Tween broth (T.G.T.B.) incubated both aerobically and anaerobically for 24 and $48 \mathrm{hr}$. Contrary to expectation, the results immediately after freeze-drying showed that the cultures from broth, particularly those incubated anaerobically for $24 \mathrm{hr}$., gave higher survival rates than those from agar (Exp. 1, Table 2).

Three further experiments were made in which the standard method (growth on agar slopes for $24 \mathrm{hr}$. anaerobically) was compared with preparation of the culture by anaerobic incubation of broth for $24 \mathrm{hr}$. Table 2, which 
includes data covering an 18 months storage period, shows the variable results obtained, the different methods of preparing the culture resulting in similar percentage survivals. In these experiments the broth cultures were centrifuged and the cells taken up directly in the suspending medium; in further studies the centrifuged cells were washed twice in $0.85 \% \mathrm{NaCl}$ to remove any free acid before resuspension. No difference was found between the percentage survivals of washed and unwashed cells.

Table 2. Effect of growth medium on the survival of freeze-dried cultures of Lactobacillus acidophilus $A 1$

\begin{tabular}{|c|c|c|c|c|c|}
\hline \multirow[b]{2}{*}{ Exp. } & \multirow[b]{2}{*}{ Medium* } & \multicolumn{4}{|c|}{ Percentage survival after storage time, month } \\
\hline & & $0 \dagger$ & 1 & $\mathbf{3}$ & 18 \\
\hline $\mathbf{1}$ & $\begin{array}{l}\mathbf{A} \\
\mathbf{B}\end{array}$ & $\begin{array}{l}48 \cdot 2 \\
80 \cdot 2\end{array}$ & $\begin{array}{l}45 \cdot 3 \\
31 \cdot 7\end{array}$ & $\begin{array}{l}41 \cdot 7 \\
40 \cdot 3\end{array}$ & $\begin{array}{l}\text { nt } \\
16.0\end{array}$ \\
\hline 2 & $\begin{array}{l}\mathbf{A} \\
\mathbf{B}\end{array}$ & $\begin{array}{l}71 \cdot 2 \\
51 \cdot 7\end{array}$ & $\begin{array}{l}37 \cdot 5 \\
20 \cdot 6\end{array}$ & $\begin{array}{l}43 \cdot 5 \\
46 \cdot 9\end{array}$ & $\begin{array}{l}17.9 \\
29.9\end{array}$ \\
\hline 3 & $\begin{array}{l}\mathbf{A} \\
\mathbf{B}\end{array}$ & $\begin{array}{l}68 \cdot 5 \\
50 \cdot 3\end{array}$ & $\begin{array}{l}66 \cdot 3 \\
67 \cdot 4\end{array}$ & $\begin{array}{l}57 \cdot 4 \\
50 \cdot 0\end{array}$ & $\begin{array}{l}32.8 \\
31.9\end{array}$ \\
\hline 4 & $\begin{array}{l}\mathbf{A} \\
\mathbf{B}\end{array}$ & $\begin{array}{l}59 \cdot 0 \\
60 \cdot 0\end{array}$ & $\begin{array}{l}59 \cdot 6 \\
51.9\end{array}$ & $\begin{array}{r}66 \cdot 6 \\
71 \cdot 3\end{array}$ & $\begin{array}{l}\text { nt } \\
\text { nt }\end{array}$ \\
\hline
\end{tabular}

* A: T.G.T.A. (Briggs, $1953 b$ ) slope incubated anaerobically for $24 \mathrm{hr}$. (standard method). B : T.G.T.B. (Briggs, $1953 b$ ) incubated anaerobically for $24 \mathrm{hr}$.

$\dagger$ Immediately after freeze-drying.

nt $=$ not tested.

\section{Effect of variation of the original count}

The original counts of strains of Lactobacillus helveticus, L. casei and $L$. brevis were between $1.0 \times 10^{8}$ and $1.0 \times 10^{9} /$ tube $(0 \cdot 1 \mathrm{ml}$.): strains of $L$. acidophilus and $L$. bulgaricus had lower original counts (between $1.0 \times 10^{7}$ and $1 \cdot 0 \times 10^{8} /$ tube) and also showed lower percentage survivals. The effect of variation of the original count was studied by freeze-drying suspensions, together with their 1/10, 1/100 and 1/1000 dilutions in milk +lactose. The immediate percentage survivals of two strains, $L$. acidophilus $\mathrm{A} 1$ and $L$. casei C14, are shown in Table 3; the figures after storage were not determined.

Table 3. Effect of suspension density on the survival of freeze-dried lactobacilli

$\begin{array}{cccc}\text { Strain } & \begin{array}{c}\text { Dilution of } \\ \text { original } \\ \text { suspension }\end{array} & \begin{array}{c}\text { Original average } \\ \text { count per tube } \\ (0 \cdot 1 \mathrm{ml} .)\end{array} & \begin{array}{c}\text { Percentage survival } \\ \text { immediately after } \\ \text { freeze-drying }\end{array} \\ \text { L. acidophilus A1 } & 0 & 12,625,000 & \mathbf{6 3 \cdot 8} \\ & 1 / 10 & \mathbf{8 8 7 , 5 0 0} & \mathbf{9 5 \cdot 6} \\ & 1 / 100 & 132,500 & \mathbf{6 5 \cdot 5} \\ \text { L. casei } \text { C14 } & 1 / 1000 & 20,725 & \mathbf{6 6 \cdot 2} \\ & 0 & 138,250,000 & \mathbf{6 3 \cdot 5} \\ & 1 / 10 & 13,580,000 & \mathbf{8 5 \cdot 4} \\ & 1 / 100 & 1,670,000 & \mathbf{8 0 \cdot 3} \\ & 1 / 1000 & 205,250 & 78 \cdot 0\end{array}$


A 1/10 dilution of the original suspension, irrespective of the number of organisms present, gave the highest percentage survival; these observations are discussed on p. 509.

The separate effects of freezing, drying and storage

It was of interest to determine the separate contributions to the total lethal effect of freezing, drying and storage. The results shown in Tables 1 and 2 and in Fig. 1 show that a much greater loss of viability occurred during the actual freeze-drying process than during storage. Table $4 \mathrm{~A}$ shows the results with two freeze-dried strains that had been stored for almost 2 years. Although the percentage survivals fell during storage, more than $8 \%$ of the original viable organisms were still alive after 22 months; this corresponded to a count of $15 \times 10^{6}$ organisms/tube $\left(0.1 \mathrm{ml}\right.$.) of Lactobacillus brevis $\mathrm{X1}$ and $22 \times 10^{6}$ of L. helveticus $\mathbf{H 5}$.

The percentage survivals of two strains of Lactobacillus acidophilus were observed after freezing in $\mathrm{CO}_{2}$-ice for $3 \mathrm{~min}$. (see p. 504), and also after the freeze-drying process had been completed (Table $4 \mathrm{~B}$ ); the greater proportion of organisms was killed during the drying stage. The percentage survival figures after 1, 3 and 18 months storage have been included in the table to illustrate the relative loss of viability during freezing, during the complete freeze-drying process and during storage.

Table 4. Survival of lactobacilli after freezing, freeze-drying and storage

Percentage survival

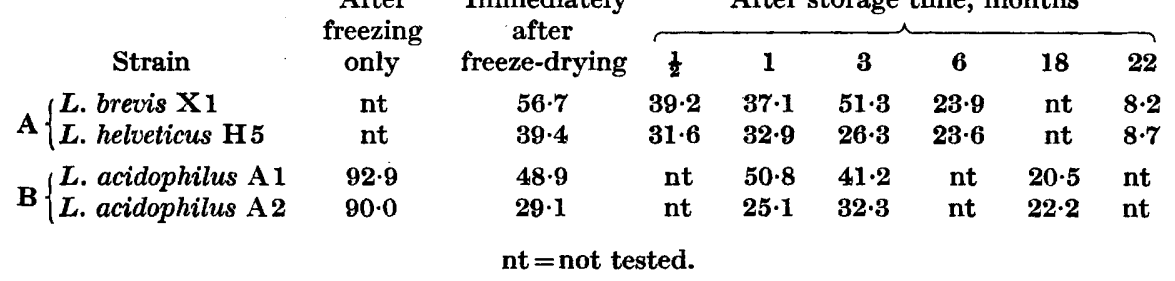

\section{Application of technique to representative cultures}

Forty-four lactobacilli, fourteen freshly isolated, representative of Briggs's (1953 $a$ ) classification were freeze-dried using the 'standard' method described on p. 504, save that $24 \mathrm{hr}$. cultures were suspended in horse serum $+8 \%$ glucose. The results, with some replicates, are shown in Table 5, together with the survival rates after 6 months storage. The growth temperatures used for the strains in each group and section (Briggs, 1953 $a$ ) are also shown, as well as the different plating techniques for the viable counts.

The data in Table 5 show that survival rate varied with species, as Proom \& Hemmons (1949) and Rhodes \& Fisher (1950) found with other organisms; strain differences were not so marked as in Record \& Taylor's (1953) work with 
Escherichia coli. All the freshly isolated cultures gave high survival rates save for two in group V; however, most of the strains in this group dried relatively poorly. Further study of group $\mathrm{V}$, for example with the organisms grown at a temperature lower than $45^{\circ}$, might prove profitable.

The indicated survival rate of $266.7 \%$ achieved by Lactobacillus buchneri $\mathrm{BC} 1$ after 6 months storage was remarkable, but the figure of $286.7 \%$ was obtained when a duplicate tube was counted. L. buchneri $\mathrm{BC} 1$ was a small coccobacillus and dispersal of clumped organisms may account for the figures obtained.

Distribution of the results of the fifty-two tests shown in Table 5 among arbitrary divisions of the survival rate range 0 to $100+\%$ gave the figures shown in Table 6 . The majority of the survival rates were over $50 \%$ immediately after drying, and over $25 \%$ after 6 months storage.

\section{DISCUSSION}

Studies of the effects on bacteria of freeze-drying are, necessarily, of long duration; the work described here is not, therefore, complete though some cultures have been dried now for over 2 years. Moreover, these investigations are not comprehensive since they represent simply an attempt to solve the problem of maintenance of stock cultures of lactobacilli; studies of the more fundamental principles and factors involved have been deliberately avoided. Particular regard has been paid to percentage survival; the total number of organisms surviving is less important than the percentage, for it is the latter that indicates the degree of selection that may have occurred. The chief factor influencing the survival rate was the suspending medium; horse serum $+8 \%$ glucose gave satisfactory results and was used in the routine drying of representative lactobacilli. The concentration $(8 \%)$ of glucose chosen, for the reason stated on p. 505, closely resembled that $(\mathbf{7 \cdot 5} \%$ ) with which Fry \& Greaves (1951) obtained their best results with a paracolon bacillus.

Differences in the medium on which the cultures were grown had little effect on the counts obtained after freeze-drying, likewise the age of the culture (between 24 and $48 \mathrm{hr}$.). However, the numbers of organisms influenced the percentage survival in that a 1/10 dilution of the original suspension, irrespective of its concentration, gave the highest number of viable organisms immediately after drying. Yet this dilution corresponded to a count before drying of $1 \times 10^{6} /$ tube with one strain of Lactobacillus and $13 \times 10^{6}$ with another. In this connexion the work of Record \& Taylor (1953) is of interest. With strains of Escherichia coli they found that 'a well-defined relationship existed between the concentration of organisms in the suspension before drying and the percentage of viable survivors recovered after reconstituting the dried product; the more dilute the suspension the lower the percentage of organisms surviving.... The dependence of percentage survival on the concentration of organisms in the suspension to be dried was shown to be due to soluble material derived from the organisms themselves.' Studies of this aspect with the lactobacilli would be of interest. 
Table 5. Survival of forty-four represent ative lactobacilli after freeze-drying in horse serum $+8 \%$ glucose

$$
\begin{aligned}
& \text { Strains, in groups } \\
& \text { and sections } \\
& \text { (see Briggs, 1953a) }
\end{aligned}
$$

\section{Group I}

L. acidophilus A 1

L. acidophilus A $1 \dagger$

L. acidophilus A 20

L. acidophilus A $20 \dagger$

L. acidophilus A3

L. acidophilus A4

L. acidophilus A 16

L. acidophilus BF 4 †

Lactobacillus PF $3 \ddagger^{\circ}$

\section{Group II}

L. bulgaricus $\mathrm{B2}$

L. bulgaricus $\mathrm{B} 2 \dagger$

L. acidophilus $\mathrm{A} 18$

L. bulgaricus Y 48

L. bulgaricus SM10‡

\section{Group III}

L. bulgaricus B 14

Lactobacillus PR 8末

\section{Group IV \\ L. helveticus $\mathrm{H5}$ \\ L. helveticus $\mathrm{C} 10$ \\ L. casei helveticus 09 \\ L. casei helveticus $09 \$ \dagger$ \\ L. helveticus YOG3‡}

\section{Group V}
L. lactis $\mathbf{L} 1$
L. lactis $\mathbf{L} 1 \ddagger$
L. thermophilus THI
L. leichmannii LE2
L. leichmannii LE2 $†$
L. leichmannii LE6
L. leichmannii LE6†
L. lactis AH7
L. lactis AHr $+\dagger$
Lactobacillus CS7‡

\section{Group VI}
L. casei $\mathrm{C5}$
L. casei $\mathbf{C 2 4}$
L. plantarum $\mathbf{P} 4$
L. casei $\mathrm{H} 1$
L. plantarum SL5

Percentage survival

after 6 months storage

\begin{tabular}{rr}
\multicolumn{1}{c}{$0 *$} & \multicolumn{1}{c}{6} \\
& \\
$14 \cdot 4$ & \\
$60 \cdot 7$ & $31 \cdot 0$ \\
$7 \cdot 4$ & $26 \cdot 1$ \\
$50 \cdot 0$ & $29 \cdot 0$ \\
$27 \cdot 0$ & $13 \cdot 9$ \\
$30 \cdot 7$ & $102 \cdot 2$ \\
$66 \cdot 4$ & $7 \cdot 4$ \\
$55 \cdot 3$ & $106 \cdot 2$ \\
$96 \cdot 2$ & $24 \cdot 6$ \\
& $122 \cdot 1$
\end{tabular}

$9 \cdot 0$

$24 \cdot 6$

22.1
Technique

Incubation for viable temperature count

$\begin{array}{rr}18.0 & 16.5 \\ 19.9 & 7 \cdot 5 \\ 56 \cdot 6 & 31 \cdot 3 \\ 38.2 & 7 \cdot 1 \\ 46.8 & 17 \cdot 6\end{array}$

$37^{\circ}$

(a)

$37^{\circ}$

$55 \cdot 7$

$43 \cdot 5$

$37^{\circ}$

(b)

$86 \cdot 0 \quad 115 \cdot 5$

$39 \cdot 4$

$117 \cdot 4$

$\mathbf{4 7 \cdot 3}$

63.7

93.8

$23 \cdot 6$

$96 \cdot 6$

90.2

$28 \cdot 7$

$15 \cdot 3$

$37^{\circ}$

(a)

(b)

1.3

$7 \cdot 6$ )<smiles>C1CCC1</smiles> 


\section{Freeze-drying of lactobacilli}

Table 5 (cont.)

Strains, in groups

and sections

(see Briggs, 1953a)

Group VII

L. brevis X 1

L. brevis $\mathrm{X} 2$

L. pastorianus $\mathrm{T} 5$

L. pentoaceticus $\mathrm{E} 2$

L. buchneri $\mathrm{BC} 1$

L. brevis BR $11+$

L. brevis SL 15:

Group VIII

L. fermenti F1

L. fermenti $\mathbf{F} 4$

L. fermenti AH18 Bt

Section I

L. jugurt J 1

Lactobacillus AH4

Section II

Lactobacillus RF 1:

Section III

L. acidophilus A7

L. casei $\mathrm{C28}$

Section IV

L. bifidus $\mathrm{S} 6$

* Immediately after freeze-drying.

$\uparrow$ Result of duplicate experiments.

$¥$ Freshly isolated strains.

Plating techniques (see p. 504): (a) double layer agar plates; (b) single layer plates in anaerobic jars.

Since, in addition to errors in technique, particularly in dilution and plating, the apparatus used might have been responsible for some variations, comparisons were made between this and an Edwards's (W. Edwards and Co. (London) Ltd.) model L 5 (centrifugal) freeze-drier. However, there was little difference between the results obtained with the two sets of apparatus, variability being equally great and survival rates similar.

Our observations agree closely with those of Fry \& Greaves (1951); they emphasize the importance of determining viable numbers and percentage survivals after freeze-drying and during storage. They also recognize the importance of the suspending medium and advise the inclusion of 5 to $10 \%$ of lactose or glucose. No significant differences were found in their results when the number of organisms to be dried was varied, but an 'old' culture $(20 \mathrm{hr}$.) dried more satisfactorily than a young one $(4 \mathrm{hr}$.). (The youngest cultures of lactobacilli dried were $24 \mathrm{hr}$. old.) Fry \& Greaves suggested that their methods 
and results might be applicable to other species of bacteria, and aimed at a survival of $1 \%$ over several years; it now seems that this should not be difficult to attain with the lactobacilli. The figures in Table 6 justify, from the

Table 6. Distribution of survival rates from

Table 5 in the range 0 to $100+\%$

$\begin{array}{ccc}\begin{array}{c}\text { Arbitrary divisions } \\ \text { of survival rate } \\ \text { range } 0 \text { to } 100+\%\end{array} & \begin{array}{c}\text { Immediately after } \\ \text { freeze-drying }\end{array} & \begin{array}{c}\text { After } 6 \text { months } \\ \text { arbitrary division } \\ \text { storage }\end{array} \\ 0 \text { to } 1 \% & 0 & 5 \\ 1 \text { to } 10 \% & 6 & 8 \\ 10 \text { to } 25 \% & 6 & 11 \\ 25 \text { to } 50 \% & 11 & 13 \\ \mathbf{5 0} \text { to } 100+\% & 29 & 15\end{array}$

standpoint of survival rate, the methods used for freeze-drying lactobacilli. Physiological and serological studies of lactobacillus cultures and antisera freeze-dried in this work are described by Sharpe \& Wheater (1955).

We wish to thank Dr A. T. R. Mattick for helpful advice and suggestions.

\section{REFERENCES}

Briggs, M. (1953a). The classification of lactobacilli by means of physiological tests. J. gen. Microbiol. 9, 234.

Briggs, M. (1953b). An improved medium for lactobacilli. J. Dairy Res. 20, 36.

Fry, R. M. \& Greaves, R. I. N. (1951). The survival of bacteria during and after drying. J. Hyg., Camb. 49, 220.

NAYlOR, H. B. \& Smith, P. A. (1946). Factors affecting the viability of $S$. marcescens during dehydration and storage. J. Bact. 52, 565.

Proom, H. \& Hemmons, L. M. (1949). The drying and preservation of bacterial cultures. J. gen. Microbiol. 3, 7.

Record, B. R. \& TAYLOR, R. (1953). Some factors influencing the survival of Bacterium coli on freeze-drying. J. gen. Microbiol. 9, 475.

Rhodes, M. \& Fisher, P. J. (1950). Viability of dried bacterial cultures. J. gen. Microbiol. 4, 450.

Sharpe, M. E. \& Wheater, D. M. (1955). Physiological and serological characteristics of freeze-dried lactobacilli. J. gen. Microbiol. 12, 513.

Speck, M. L. \& Myers, R. P. (1946). The viability of dried Lactobacillus bulgaricus cultures as affected by the temperature of the reconstituting fluid. J. Bact. 51, 587.

SwiFt, H. F. (1937). A simple method for preserving bacterial cultures by freezing and drying. J. Bact. 33, 411.

\section{EXPLANATION OF PLATE}

Freeze-drying apparatus showing silica gel column, vacuum pump, freeze-drying tubes in dish of powdered solid $\mathrm{CO}_{2}$, 'Vacustat', insulated box, desiccator containing basket of drying tubes and dish of phosphorus pentoxide, manifold, vacuum tester, jeweller's flame and rack of completed tubes ready for storage. 
Journal of General Microbiology, Vol. 12, No. 3

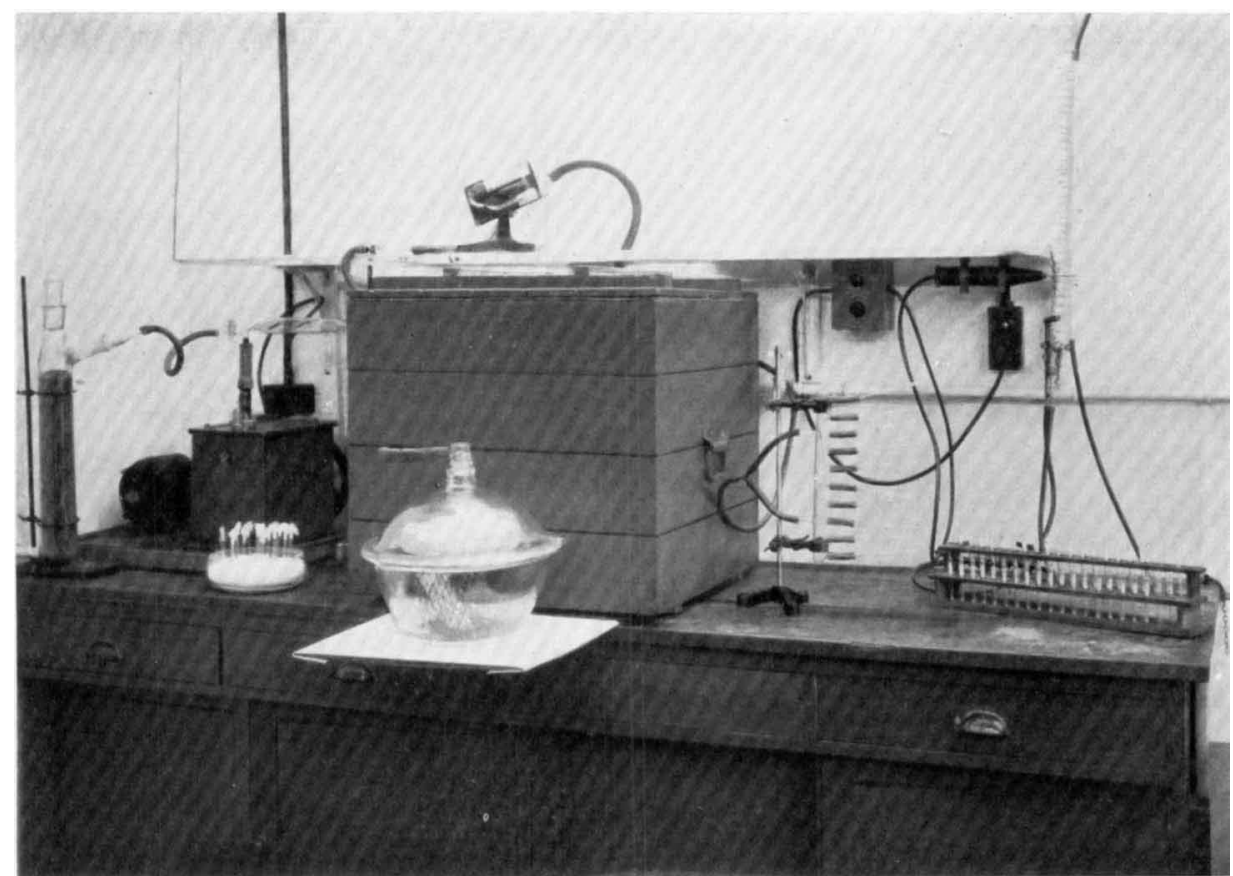

M. Briggs, G. Tuli, L. G. M. Newland \& C. A. E. Briggs-Freeze-drying of lactobacilli. Plate 1

(Facing p. 512) 